\title{
ANALISIS PERSEPSI, PREFERENSI DAN SIKAP TEUNGKU DAYAH SERTA PENGARUHNYA TERHADAP PERILAKU MENABUNG DI BANK SYARIAH
}

Muhammad Riza

*Fakultas Ekonomi dan Bisnis Islam, IAIN Langsa

\begin{abstract}
This study aims to test and analyze the influence of perceptions, preferences, and attitude of teungku dayah on saving behavior in Islamic banks. The independent variables used in this study are perceptions, preferences, and attitudes. The dependent variable used in this study is saving behavior in Islamic banks. This study uses quantitative research methods with a survey approach. The population in this study is tengku dayah in the city of langsa totaling 45 tengku dayah, the sample in this study uses probability sampling technique with the type of sampling simple random sampling while the sample size is obtained from the calculation using the Slovin formula with a $5 \%$ error rate of 40 tengku dayah. The data sources in this study are primary data in the form of questionnaires. The data source in this study is primary data. Data analysis techniques used were parametric statistics, with multiple linear regression analysis. Measurement of questionnaires answered by respondents used a Likert scale using Statistical Package for the Social Sciences (SPSS) 22. The results of this study indicate that the perception of teungku dayah on saving behavior in Islamic banks has a positive and significant effect. While the preference and attitude variables do not affect the savings behavior in Islamic banks. While the value of adjusted $\mathrm{R} 2$ is 0.62 which shows the influence of the independent variable on the dependent variable that can be explained by the equation model is $62 \%$ and the remaining $38 \%$ is influenced by other factors.
\end{abstract}

Keywords: Perceptions, Preferences, Attitude, Saving Behavior, Islamic Banks 


\begin{abstract}
Abstrak
Penelitian ini bertujuan untuk menguji dan menganalisis pengaruh persepsi, preferensi, dan sikap teungku dayah terhadap perilaku menabung di bank syariah. Variabel independen yang digunakan dalam penelitian ini adalah persepsi, preferensi, dan sikap. Variabel dependen yang digunakan dalam penelitian ini adalah perilaku menabung di bank syariah. Penelitian ini menggunakan metode penelitian kuantitatif dengan pendekatan survei. Populasi dalam penelitian ini adalah tengku dayah di kota langsa yang berjumlah 45 tengku dayah, sampel dalam penelitian ini menggunakan teknik probability sampling dengan jenis pengambilan sampel simple random sampling sedangkan ukuran sampel diperoleh dari perhitungan menggunakan rumus Slovin dengan Tingkat kesalahan 5\% dari 40 tengku dayah. Sumber data dalam penelitian ini adalah data primer dalam bentuk kuesioner. Sumber data dalam penelitian ini adalah data primer. Teknik analisis data yang digunakan adalah statistik parametrik, dengan analisis regresi linier berganda. Pengukuran kuesioner yang dijawab oleh responden menggunakan skala likert menggunakan Paket Statistik untuk IImu Sosial (SPSS) 22. Hasil penelitian ini menunjukkan bahwa persepsi teungku dayah pada perilaku menabung di bank syariah memiliki pengaruh positif dan signifikan. Sedangkan variabel preferensi dan sikap tidak mempengaruhi perilaku menabung di bank syariah. Sedangkan nilai adjusted R2 adalah 0,62 yang menunjukkan pengaruh variabel independen terhadap variabel dependen yang dapat dijelaskan oleh model persamaan adalah $62 \%$ dan sisanya $38 \%$ dipengaruhi oleh faktor lain.
\end{abstract}

Kata kunci: Persepsi, Preferensi, Sikap, Perilaku Tabungan, Bank Syariah 


\section{PENDAHULUAN}

Menurut Undang-undang Perbankan Syariah Pasal 1 Ayat 2 Bank adalah badan usaha yang menghimpun dana dari masyarakat dalam bentuk simpanan dan menyalurkannya kepada masyarakat dalam bentuk kredit dan/atau bentuk lainnya dalam rangka meningkatkan taraf hidup rakyat. Bank dalam perekonomian memiliki tempat yang teramat penting sebagai lembaga yang dapat mempengaruhi kegiatan perekonomian, di samping itu bank merupakan aktor dalam pelaksanaan kebijakan moneter. Bank menjadi mediator dalam mempengaruhi jumlah uang beredar yang merupakan sasaran kebijakan moneter (Syahmiruddin Pane, 2011: 11).

Seiring dengan perkembangan bank syariah di Indonesia yang semakin pesat, Bank Indonesia ( $\mathrm{BI}$ ) telah berusaha keras untuk mendorong tumbuhnya bank syariah yang kuat secara fnansial dan selalu berpedoman kepada ketentuan-ketentuan syariah. Perkembangan lembaga keuangan syariah tersebut meliputi perkembangan perbankan syariah, asuransi syariah, pasar modal syariah, reksadana syariah, obligasi syariah, leasing (ijarah muntahiyyah bittamlik), baitul mal wat tamwil, koperasi syariah, pegadaian syariah dan berbagai bentuk bisnis syariah lainnya (Moh. Jatim, 2014: 1).

Tabel 1

Perkembangan Jumlah Bank Syariah di Indonesia

\begin{tabular}{lcccccccccc}
\hline \multicolumn{1}{c}{ Indikator } & $\mathbf{2 0 0 9}$ & $\mathbf{2 0 1 0}$ & $\mathbf{2 0 1 1}$ & $\mathbf{2 0 1 2}$ & $\mathbf{2 0 1 3}$ & $\mathbf{2 0 1 4}$ & $\mathbf{2 0 1 5}$ & $\mathbf{2 0 1 6}$ & $\mathbf{2 0 1 7}$ & $\mathbf{2 0 1 8}$ \\
\hline BUS & 6 & 11 & 11 & 11 & 11 & 12 & 12 & 13 & 13 & 14 \\
Jumlah Kantor & 711 & 1.215 & 1.401 & 1.745 & 1.998 & 2.163 & 1.990 & 1.869 & 1.825 & 1.875 \\
UUS & 25 & 23 & 24 & 24 & 23 & 22 & 22 & 21 & 21 & 20 \\
Jumlah Kantor & 287 & 262 & 336 & 517 & 590 & 320 & 311 & 332 & 344 & 354 \\
BPRS & 138 & 150 & 155 & 158 & 163 & 163 & 163 & 166 & 167 & 167 \\
Jumlah Kantor & 225 & 286 & 364 & 401 & 402 & 439 & 446 & 453 & 441 & 495 \\
\hline
\end{tabular}

Sumber: Data Statistik Perbankan Syariah OJK 2018 yang diolah

Tabel 1 menunjukkan perkembangan perbankan syariah di mana pada tahun 2009 terdapat 6 (enam) Bank Umum Syariah di Indonesia yang kemudian naik dua kali lipat menjadi 14 (tiga belas) dalam kurun waktu 9 (sembilan) tahun. Perkembangan ini dikuti dengan bertambah pula jumlah kantor yang pada tahun 2009 berjumlah 711 kantor menjadi 1.875 kantor. Begitu pula UUS dan BPRS yang terus berkembang di Indonesia. Semakin berkembangnya bank syariah berimplikasi pada semakin besarnya tantangan yang harus dihadapi bank syariah, di mana tantangan terbesar adalah untuk mempertahankan citra dan nama baik di mata nasabah agar tetap menjaga 
kepercayaan serta loyalitas nasabah kepada bank syariah (Haifa Najib, 2016: 3-4).

Bank Indonesia menjelaskan bahwa dalam mendorong praktik perbankan syariah yang kuat dan sehat secara fnansial dan senantiasa mengacu kepada prinsip-prinsip syariah, maka bank syariah diharapkan dapat melaksanakan prinsip-prinsip GCG (Good Corporate Governence) berupa transparansi, akuntabilitas, tanggung jawab, kebebasan dan kewajaran dan kepatuhan kepada ketentuan-ketentuan syariah. Penerapan GCG terbukti di dalam penelitian di beberapa lembaga keuangan syariah di dunia Muslim dapat meningkatkan reputasi dan kepercayaan masyarakat kepada bank syariah (Ade Sofyan Mulazid, 2017: 3).

Secara historis lembaga pendidikan Islam yang pertama sekali muncul khususnya di Aceh adalah dayah, lembaga ini telah berlangsung cukup lama bersamaan dengan berkembangnya ajaran agama Islam yang disebarluaskan oleh para ulama atau para tokoh agama Islam. Dayah menurut catatan pakar pendidikan, merupakan lembaga pendidikan paling awal di Nusantara. Peran dan fungsi dayah dalam pembelajaran sosial telah menunjukkan prestasi yang patut dibanggakan pada masa lalu (Jurnal Al-Bayan, 2015: 53).

Dayah dan Balai Pengajian merupakan lembaga pendidikan Islam tertua di Aceh yang telah lama berkiprah dalam membangun sumber daya manusia (SDM). Pada permulaannya kegiatan belajar-mengajar ini hanya berlangsung di rangkang-rangkang, dengan pelajaran utamanya terfokus pada pelajaran agama dan mengajarkan kitab-kitab Arab tertentu yang telah ditetapkan oleh pimpinan. Perumpamaan pendidikan Dayah setara dengan Madrasah Aliyah (MA) atau sekolah lanjutan tingkat atas (SLTA), sedangkan untuk kegiatan pengajian yang diselenggarakan di meunasah, setingkat dengan Tsanawiyah atau sekolah lanjutan pertama pada kebanyakan menggunakan kitab rujukan berbahasa melayu seperti kitab fikih, usuluddin dan lainnya (Hamidansyah, 2011:1).

Kekuatan dayah di Aceh pada dasarnya lebih tertumpu pada teungku, ini dikarenakan oleh beberapa faktor, di antaranya adalah kadar ilmu yang dimilikinya luas dan mendalam, kearifan wataknya yang disegani, sikap dan tingkah laku amaliyahnya yang di teladani umat, pengayomannya kepada masyarakat kapanpun diminta kesediaanya, selanjutnya yang sangat mendasar adalah pada keikhlasannya dalam perjuangan yang sangat dirasakan, yang tidak terdapat kadar keikhlasan ini pada institusi pendidikan formal lainnya (Hamidansyah, 2011: 53).

Disamping itu, dari hasil observasi awal yang penulis lakukan menggunakan salah satu teknik pengumpulan data yaitu wawancara (Interview) dan instrumen pengumpulan data berupa wawancara sederhana (un-guided interview) dan menye- 
barkan angket penelitian dengan beberapa teungku dayah di Kota Langsa didapati sebuah persepsi bahwa adanya rasa ketidakpercayaan atau keyakinan dari teungku dayah yang tidak menjadi nasabah pada Bank Syariah. Karena menurut mereka walau secara konsep bank syariah sudah baik, akan tetapi dalam praktiknya Perbankan Syariah masih menunjukkan ketidaksesuaian dengan konsep syariah yang ada (Hasil Observasi Peneliti 15 Juni 2017).

Hal tersebut didukung dengan hasil survey OJK dari jumlah indeks literasi keuangan Indonesia sampai dengan tahun 2016 indeks literasi keuangan sebesar 29,66\% dan indeks inklusi sebesar 67,82 \% sedangkan jika dibandingkan dengan indeks literasi dan inklusi terhadap keuangan syariah terdapat gab yang sangat signifikan, padahal mayoritas penduduk Indonesia sebesar 87,18\% atau 207,2 juta jiwa adalah Muslim (http:// demografi.bps.go.id), dan jumlah indeks literasi keuangan syariah sebesar $8,11 \%$ dan indeks inklusi keuangan syariah sebesar 11,06\% (http://ojk.go.id).

Dalam kehidupan sehari-hari perilaku konsumen berbeda-beda dalam Islam perilaku konsumen harus mencerminkan hubungan dirinya dengan Allah SWT. Islam telah mengatur segenap perilaku manusia dalam memenuhi kebutuhan hidupnya yaitu tidak menyimpang dari ajaran agama Islam. Reaksi yang berbeda akan menggambarkan perilaku yang berbeda yaitu konsumen yang berbeda maka akan memberikan reaksi yang berbeda pula dalam hal perasaan terhadap informasi yang sama, sikap biasanya memainkan peranan utama dalam membentuk perilaku dalam memutuskan merek apa yang akan dibeli dan toko mana yang akan dijadikan langganan, konsumen secara khas memilih merek atau toko yang dievaluasi secara paling menguntungkan (Heri Sudarsono, 2007: 167).

Berkaitan dengan preferensi, konsumen akan memberikan harapannya sebagai standar atau acuan. Harapan teungku dayah dalam memilih suatu produk pun memprioritaskan pada kepuasannya, yaitu kepuasan akan kesesuaian antara teori dan praktek bank syariah. Jadi dalam kontek preferensi konsumen adalah harapan perkiraan atau keyakinan konsumen tentang apa yang akan diterimanya karena preferensi merupakan hasil dari evaluasi. Persepsi konsumen berkaitan erat dengan kesadarannya sehingga apa yang dilakukan oleh konsumen merupakan kenyataan yang obyektif yang akan mempengaruhi tindakannya seperti keputusan membeli, sehingga persepsi dan perilaku itu sangat berkaitan dengan keputusan memilih atau menggunakan suatu barang atau jasa, jadi apabila persepsi dan perilaku terhadap perbankan syariah baik maka preferensinya cenderung terhadap perbankan syariah (Kasmir, 2004: 17).

Adapun beberapa hasil kajian atau penelitian terdahulu yang relevan dengan penelitian ini adalah penelitian yang dilakukan oleh Hamidi (2000) dengan judul, 
“Persepsi dan Sikap Masyarakat Santri Jawa Timur Terhadap Bank Syariah”, penelitian ini dianalisis secara sederhana menggunakan pendekatan kualitatif dan hasil penelitian ini menunjukkan bahwa persepsi masyarakat muslim Jawa Timur adalah positif terhadap prinsip dasar bank syariah, dengan alasan bahwa pada manajemen keuangan, sebagian pelanggan dari masyarakat Muslim juga menggunakan lembaga keuangan lain untuk menabung, uang pinjaman dan layanan lain dari lembaga keuangan dan perbankan, sedangkan yang menjadi alasan utama masyarakat muslim untuk memilih bank syariah adalah karena kesesuaiannya dengan Islam syariah (hukum), keamanan, dan kedekatan dengan kehidupan mereka.

Penelitian yang relevan selanjutnya dilakukan oleh AM. M. Hafidz MS dkk (2014) dengan judul, "Peran dan Potensi Kyai Pesantren dalam Pengembangan Lembaga Keuangan Syariah di Pekalongan Tinjauan Wom Marketing dan Buzz Marketing”, dengan metode Penelitian yang digunakan adalah metode kualitatif tinjauan wom marketing dan buzz marketing dan hasil penelitian ini menunjukkan bahwa karena kekuatan mereka, karisma, pengetahuan, otoritas di sekolah asrama, leverage influentality, keahlian, dan pengaruh jaringan sosial, Kyai Pesantren memiliki potensi untuk memasarkan Islamic Financial Institutions dengan menciptakan buzz dan pemasaran WoM. Peran mereka sebagai pemasar dapat memberikan pendidikan dan pembelajaran ekonomi Islam, Syariat Islam dan fiqh muamalah dan membangun beberapa unit bisnis untuk mengajar siswa mereka secara operasional dan praktis pada ekonomi Islam serta menyamar sebagai Dewan Pengawas Syariah di Lembaga Syariah Islam sebagai wali kepatuhan syariah dan disamping itu mereka dapat menyebarluaskan peran Lembaga Islam Syariah kepada masyarakat ketika memberi mereka kuliah.

Penelitian selanjutnya dilakukan oleh Murdianingsih Sri (2015) dengan judul "Analisa Persepsi Sikap dan Perilaku Santri Pondok Pesantren di Kota Salatiga Terhadap Perbankan Syariah dengan Sikap sebagai Variabel Moderating”, penelitian ini menggunakan metode kuantitatif karena bertujuan untuk mengkonfirmasi data yang didapatkan di lapangan dengan teori yang ada. Penelitian ini menggunakan teknik pengumpulan data dengan metode kuesioner, studi pustaka dan wawancara, data diolah dengan mengunakan uji reliabilitas, validitas, uji asumsi klasik dan regresi berganda dan hasil analisa data menunjukkan bahwa persepsi ekspektasi berpengaruh positif terhadap perilaku, dan persepsi situasi lingkungan berpengaruh negatif terhadap perilaku, namun setelah dimoderasi dengan sikap situasi ligkungan berpengaruh terhadap perilaku. 


\section{LANDASAN TEORI}

\section{Bank Syariah}

Secara bahasa bank berasal dari kata bangue (bahasa Perancis) dan dari kata banco (bahasa Italia) yang berarti peti/ lemari atau bangku (M. Syafi'i Antonio, 2006: 2). Sedangkan dalam bahasa arab, bank biasa disebut dengan mashraf yang berarti tempat berlangsung saling menukar harta, baik dengan cara mengambil ataupun menyimpan atau selain untuk melakukan muamalah. (Djazuli, 2001: 53). Menurut Karmen dan Antonio terdapat dua pengertian antara Bank Islam dan bank yang beroperasi dengan prinsip syari'ah Islam.

Bank Islam adalah bank yang beroperasi sesuai dengan prinsip-prinsip islam. Sementara bank yang beroperasi sesuai prinsip syariah Islam adalah Bank yang dalam operasinya mengikuti ketentuan-ketentuan syariah Islam, khususnya yang menyangkut tata cara bermuamalat secara islam yaitu menjauhi praktek-praktek yang dikhawatirkan mengandung unsur-unsur riba untuk diisi dengan kegiatan-kegiatan investasi atas dasar bagi hasil dan pembiayaan perdagangan (Karnaen Perwataatmadja, 2002: 10).

\section{Dayah}

Haidar Putra Daulay menyebutkan, perubahan kata Zawiyah (Arab) menjadi Dayah (Aceh) karena dipengaruhi dialektika orang-orang Aceh yang sering menggunakan istilah atau kata-kata singkat untuk menyebut sesuatu. Perubahan dialek ini juga ada kaitannya dengan perubahan bentuk atau perpindahan tempat belajar dari sudut-sudut mesjid menjadi lembaga pendidikan khusus yang diyakini keberlangsungannya hanya dengan mengandalkan keikhlasan semata, bukan untuk dikomersilkan dalam bentuk apapun. Menurut salah satu sumber, istilah dayah berasal dari kata zawiyah yang kemudian akibat pengaruh dialek Aceh berubah menjadi kata "dayah" (Hamidansyah, 2011: 5).

Dalam sejumlah literatur, "Zawiyah" adalah suatu tempat dimana orang-orang Islam melakukan proses pendidikan kerohanian (pendidikan suluk). Sedangkan “Dayah" merupakan lembaga dakwah yang bertujuan mengajari dan mentransfermasi ilmu-ilmu agama Islam kepada masyarakat dan generasi Islam. Istilah Dayah dapat di urutkan dari istilah bahasa Arab yaitu dari kata ( دعى- يدعو- دعاء- دعوة- د يه ), yang berarti tempat atau lembaga penyiaran agama Islam. Dengan demikian istilah "dayah" juga memiliki relevansi dengan kata "da'a", yaitu lembaga penyampaian dan penyiaran agama Islam. Saifuddin Dhuhri menyebutkan bahwa:

dayah bermula pertama sekali didirikan di Aceh yaitu di Cot Kala oleh seorang ulama bernama Muhammad Amin, atau lebih dikenal dengan Teungku Chik Cot Kala. Dayah ini juga masyhur dengan pendidikan tinggi yang setara dengan perguruan tinggi pada saat ini (Hamidansyah, 2011: 6). 


\section{Teuku Dayah}

Teungku dayah adalah figur teungku yang paling utama. la merupakan sosok teungku yang sangat berpengaruh dalam masyarakat Aceh baik dalam aspek pembelajaran keagamaan (religious teaching) maupun sosial dan politik. Sebagai pemimpin tertinggi dalam suatu dayah, maka yang terakhir memiliki eksistensi struktural tertinggi dibanding dengan para teungku lainnya, pemilik kharisma atau kewibawaan tertinggi, penghormatan tertinggi dan tentu saja yang paling diikuti setiap perkataan dan tindakannya oleh masyarakat Aceh. Karena kekuatan pesona kharismatiknya tidak tergantikan, maka seorang teungku dayah adalah pemimpin seumur hidup di dayah maupun di masyarakatnya. Dengan kenyataan sosiologis seperti itu, maka dapat dipahami bahwa pernyataanpernyataan teungku dayah merupakan peuneutoh haba (pemberi kesimpulan akhir) terhadap berbagai permasalahan yang kemudian secara serta merta (taken from granted) diikuti oleh masyarakat Aceh (Nirzalin Armia, 2014: 18).

\section{Persepsi}

Persepsi adalah proses interpretasi seseorang atas lingkungannya (Robert Kreitner, 2005: 208). Persepsi adalah proses yang digunakan oleh individu untuk memilih, mengorganisasi, dan menginterpretasi masukan informasi untuk menciptakan gambaran dunia yang memiliki arti. Persepsi tidak hanya bergantung pada rangsangan fisik, tetapi juga pada rangsangan yang berhubungan dengan lingkungan sekitar dan keadaan individu yang bersangkutan. Dalam pemasaran, persepsi itu lebih penting dari pada realitas, karena persepsi itulah yang akan mempengaruhi perilaku aktual konsumen. Orang dapat memiliki persepsi yang berbeda-beda atas obyek yang sama (Kotler dan Keller, 2007: 248).

\section{Preferensi}

Preferensi menurut kamus besar bahasa Indonesia adalah pilihan, kecendrungan, kesukaan (Departemen Pendidikan Nasional, 2005: 894). Preferensi adalah pilihan-pilihan yang dibuat oleh para konsumen atas produk-produk yang dikonsumsinya. Kekuatan preferensi konsumen akan menentukan produk-produk apa saja yang mereka beli dari pendapatan mereka yang terbatas, dan juga permintaan (demand) untuk produk-produk tersebut (Rumapea, 1994: 300).

Preferensi juga diartikan sebagai pilihan suka atau tidak suka oleh seseorang terhadap suatu produk barang dan jasa yang dikonsumsi. Kotler berpendapat bahwa:

preferensi digambarkan sebagai sikap konsumen terhadap produk dan jasa sebagai evaluasi dari sifat koqnitif seseorang, perasaan emosional, dan kecendrungan bertindak melalui objek/ide (Kotler, 2005: 154). 


\section{Sikap}

Sikap adalah perbuatan yang berdasarkan pendirian dan keyakinan (Departemen Pendidikan Nasional, 2005: 1063). Sikap belum merupakan predisposisi (syarat awal) tindakan suatu perilaku (Notoatmodjo, 2007: 143). Sciffman dan Kanuk seperti dikutip Simon Simamura mengatakan bahwa:

sikap adalah ekspresi perasaan (inner feeling), yang mencerminkan apakah seseorang senang atau tidak senang, suka atau tidak suka, dan setuju atau tidak terhadap suatu objek. Objek yang dimaksud bisa berupa merk, layanan, dan lain-lain (Simamora, 2000: 152).

\section{Perilaku Konsumen}

Menurut Kotler dan Keller (2008), perilaku konsumen adalah studi tentang bagaimana individu, kelompok, dan organisasi memilih, membeli, menggunakan, dan bagaimana barang, jasa, ide, atau pengalaman untuk memuaskan kebutuhan dan keinginan mereka. Sedangkan menurut Mangkunegara perilaku konsumen merupakan suatu tindakan-tindakan yang dilakukan oleh individu atau kelompok yang berhubungan dengan proses pengambilan keputusan dalam mendapatkan dan menggunakan barang-barang atau jasa ekonomi yang dapat dipengaruhi oleh lingkungan (Mangkunegara, 2009: 4).

\section{METODE}

Penelitian ini menggunakan data kuantitatif dengan teknik analisis statistic parametric, dengan analisis regresi linear berganda. Teknik analisis data dalam penelitian ini meliputi uji keabsahan data, terdiri dari uji validitas, uji reabilitas. Uji asumsi klasik, terdiri dari uji asumsi klasik, uji normalitas, uji multikolinearitas, uji heterokedastisitas dan uji hipotesis, terdiri dari uji hipotesis, analisis regesi linear berganda, uji model $\mathrm{r}^{2}$ (koefisien determinasi), uji f (uji model), uji t (uji parsial) (Juliandi dan Irfan, 2013: 128). Adapun model persamaan regresi berganda adalah sebagai berikut:

$$
Y=\alpha+b_{1} x_{1}+b_{2} x_{2}+b_{3} x_{3} Y=\alpha+b_{1} x_{1}+b_{2} x_{2}+b_{3} x_{3}+e
$$
dimana:

$\begin{array}{ll}\mathrm{Y} & : \text { Perilaku menabung di Bank Syariah } \\ \alpha & : \text { Konstanta } \\ b_{1} b_{2} b_{3} b_{1} b_{2} b_{3} & : \text { Koefisien korelasi ganda } \\ x_{1} x_{1} & : \text { Persepsi Tengku Dayah Terhadap Bank Syariah } \\ x_{2} x_{2} & : \text { Preferensi Tengku Dayah Terhadap Bank Syariah } \\ x_{3} x_{3} & : \text { Sikap Tengku Dayah Terhadap Bank Syariah }\end{array}$




\section{HASIL DAN PEMBAHASAN}

Dalam Rangka menjawab hipotesis yang telah diajukan maka dilakukan serangkaian pengujian dan analisis. Diantara uji dan analisis tersebut adalah uji asumsi (multikolinearitas, normalitas, heterokedastisitas, autokorelasi), uji T dan uji F.

\section{Uji Asumsi Klasik}

\section{a. Uji Normalitas}

Uji normalitas dimaksudkan untuk menguji apakah residual yang telah distandarisasi pada model regresi berdistribusi normal atau tidak. Nilai residual dikatakan berdistribusi normal jika nilai residual terstandarisasi tersebut sebagian besar mendekati nilai rata-ratanya. Nilai residual terstandarisasi yang berdistribusi normal jika digambarkan dengan bentuk kurva akan membentuk lonceng yang kedua sisinya melebar sampai tak terhingga (Suliyanto, 2011: 69).

Gambar 1

Hasil Uji Normalitas

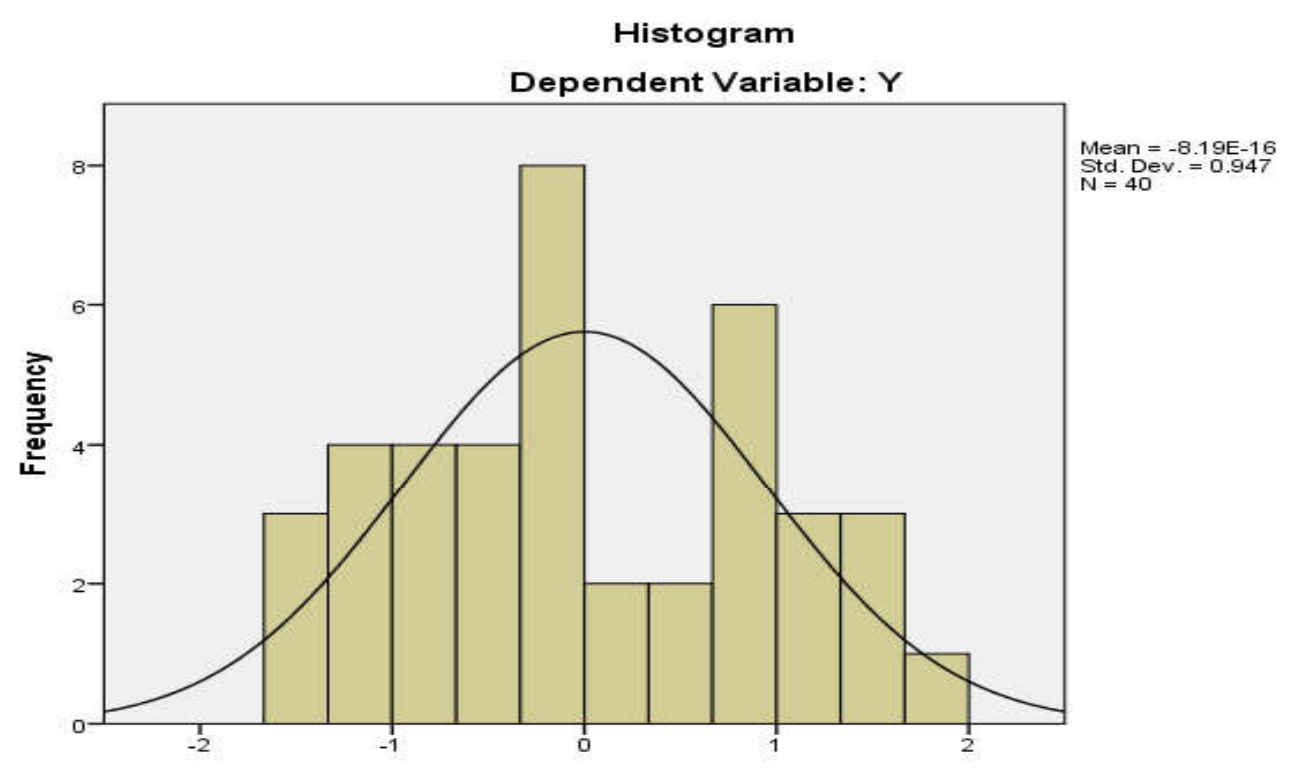




\section{b. Uji Multikolinearitas}

Tabel 2

Hasil Uji Multikolinearitas

Coefficients $^{\mathrm{a}}$

\begin{tabular}{|c|c|c|c|c|c|c|c|c|}
\hline \multirow[b]{2}{*}{ Model } & & \multicolumn{2}{|c|}{$\begin{array}{l}\text { Unstandardized } \\
\text { Coefficients }\end{array}$} & \multirow{2}{*}{$\begin{array}{c}\begin{array}{c}\text { Standardized } \\
\text { Coefficients }\end{array} \\
\text { Beta } \\
\end{array}$} & \multirow[b]{2}{*}{$t$} & \multirow[b]{2}{*}{ Sig. } & \multicolumn{2}{|c|}{ Collinearity Statistics } \\
\hline & & B & Std. Error & & & & Tolerance & VIF \\
\hline & (Constant) & 6.370 & 1.839 & & 3.464 & .001 & & \\
\hline \multirow{3}{*}{1} & $\mathrm{X}_{1}$ & .681 & .083 & .827 & 8.238 & .000 & .949 & 1.054 \\
\hline & $x_{2}$ & 137. & .083 & .174 & 1.655 & .107 & .869 & 1.151 \\
\hline & $x_{3}$ & -.284 & .116 & -.258 & -2.444 & .020 & .857 & 1.167 \\
\hline
\end{tabular}

a. Dependent Variable: $Y$

Pengujian ini bertujuan untuk mengetahui apakah tiap-tiap variabel saling berhubungan secara linear atau tidak. Uji multikolinearitas dapat dilihat dari Variance Inflation Faktor (VIF) dan nilai tolerance. Kedua ukuran ini menunjukkan sikap variabel independen manakah yang dijelaskan variabel independen lainnya. Multikolinearitas terjadi jika nilai tolerance $<<0.10$ atau sama dengan VIF $>>10$. Jika nilai VIF tidak ada yang melebihi 10, maka dapat dikatakan bahwa multikolinearitas yang terjadi tidak berbahaya (lolos uji multikolinearitas).

\section{c. Uji Linearitas}

Uji linearitas garis regresi merupakan suatu pembuktian apakah model garis linear yang ditetapkan benar-benar sesuai dengan keadaanya atau tidak. Pengujian ini dilakukan dengan menggunakan pendekatan atau analisis tabel ANOVA. Kriteria yang ditetapkan untuk menentukan kelinearitasan garis regresi adalah nilai koefisien signifikansi. Jika koefisien signifikansi lebih besar dari alpha yang ditentukan, yaitu $5 \%$, maka dapat dinyatakan bahwa garis regresi bentuk linear. Out put analisis tabel ANOVA adalah: 
Tabel 3

Hasil Uji Linearitas

ANOVA Table

\begin{tabular}{|c|c|c|c|c|c|c|c|}
\hline & & & $\begin{array}{l}\text { Sum of } \\
\text { Squares }\end{array}$ & $\mathrm{df}$ & $\begin{array}{c}\text { Mean } \\
\text { Square }\end{array}$ & $\mathrm{F}$ & Sig. \\
\hline \multirow{5}{*}{$Y * X_{1}$} & \multirow{3}{*}{ Between Groups } & (Combined) & 28.280 & 4 & 7.070 & 13.984 & .000 \\
\hline & & Linearity & 27.186 & 1 & 27.186 & 53.772 & .000 \\
\hline & & $\begin{array}{l}\text { Leviation from } \\
\text { Linearity }\end{array}$ & 1.093 & 3 & .364 & .721 & .546 \\
\hline & \multicolumn{2}{|c|}{ Within Groups } & 17.695 & 35 & .506 & & \\
\hline & \multicolumn{2}{|c|}{ Total } & 45.975 & 39 & & & \\
\hline
\end{tabular}

Sumber : Data Primer diolah SPSS, 2017

Hasil Uji linearitas menunjukkan nilai koefisien signifikansi $(0,546)$ artinya lebih besar dari alpa yang ditentukan, yaitu 0,05. Ini berarti bahwa garis regresi berbentuk linear.

\section{d. Uji Heterokidastisitas}

Dalam penelitian ini penguji menggunakan uji heterokesdasitas dengan metode analisis grafik. Metode ini dilakukan dengan mengamati scatterplot. Jika scatterplot membentuk pola tertentu, hal itu menunjukkan adanya masalah heterokesdasitas pada model regresi yang dibentuk.Sedangkan jika scatterplot menyebar secara acak maka hal itu menunjukkan tidak terjadinya masalah heterokesdasitas pada model regresi yang dibentuk.

\section{Gambar 2}

Hasil Uji Heterokidastisitas

\section{Scatterplot}

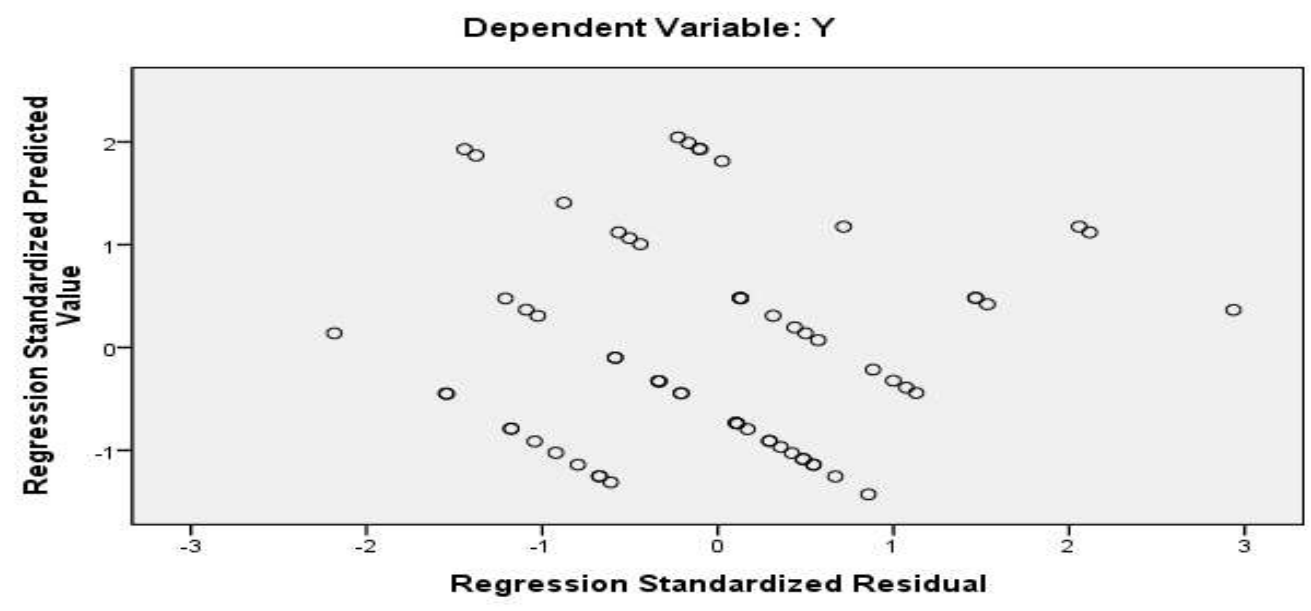


Berdasarkan output diatas terlihat bahwa plot menyebar secara acak diatas maupun dibawah angka nol pada sumbu regression studentized residual. Oleh karena itu maka berdasarkan uji heterokesdasitas menggunakan metode analisis grafik, pada model regresi yang terbentuk dinyatakan tidak terjadi gejala heterokesdasitas. (Suliyanto, 2011: 95)

\section{Uji Regesi Linear Berganda}

Analisis data yang digunakan adalah regresi linear berganda.Analisis regresi linear berganda adalah sebuah teknik yang bertujuan untuk mengetahui hubungan dari satu atau duavariabel bebas/ independen (pengetahuan, motivasi, persepsi risiko dan modal investasi minimal) dan variabel terikat/dependen (Minat berinvestasi di Pasar Modal) (Imam Ghazali, 2005: 81).

Tabel 5

Hasil Uji Regresi Linier Berganda

Coefficients $^{\mathrm{a}}$

\begin{tabular}{|c|c|c|c|c|c|c|c|c|}
\hline & \multirow{2}{*}{ Model } & \multicolumn{2}{|c|}{$\begin{array}{c}\text { Unstandardized } \\
\text { Coefficients }\end{array}$} & \multirow{2}{*}{$\begin{array}{c}\begin{array}{c}\text { Standardized } \\
\text { Coefficients }\end{array} \\
\text { Beta }\end{array}$} & \multirow{2}{*}{$\mathrm{t}$} & \multirow{2}{*}{ Sig. } & \multicolumn{2}{|c|}{ Collinearity Statistics } \\
\hline & & B & Std. Error & & & & Tolerance & VIF \\
\hline \multirow{4}{*}{1} & (Constant) & 6.370 & 1.839 & & 3.464 & .001 & & \\
\hline & $X_{1}$ & .681 & .083 & .827 & 8.238 & .000 & .949 & 1.054 \\
\hline & $X_{2}$ & .137 & .083 & .174 & 1.655 & .107 & .869 & 1.151 \\
\hline & $x_{3}$ & -.284 & .116 & -.258 & -2.444 & .020 & .857 & 1.167 \\
\hline
\end{tabular}

a. Dependent Variable: $Y$

Hasil analisis regresi berganda terhadap persepsi, preferensi dan sikap tengku dayah twrhadap perilaku menabung dibank Syariah adalah sebagai berikut :

$$
Y=6,370+0,681\left(X_{1}\right)+0,137\left(X_{2}\right)-0,284\left(X_{3}\right)+e
$$

Keterangan:

$\mathrm{Y}=$ = Perilaku menabung di bank Syariah

$\mathrm{X}_{1} \quad=$ Persepsi

$\mathrm{X}_{2} \quad=$ Preferensi

$\mathrm{X}_{3}=$ Sikap

$e^{=} \quad$ Error

Pembahasan :

$0,681 \mathrm{X}_{1} \quad$ : Jika setiap penambahan variabel Persepsi sebesar satu persen sedangkan variabel lain dianggap konstant, maka perilaku menabung di bank Syariah meningkat sebesar 0,347.

$0,137 X_{2} \quad$ : Jika setiap penambahan variabel Preferensi sebesar satu persen 
sedangkan variabel lain dianggap konstant, maka perilaku menabung di bank Syariah meningkat sebesar 0,137.

$(-) 0,284 X_{3}$ : Jika setiap penambahan variabel Sikap sebesarsatupersensedangkan variabel lain dianggap konstant, maka perilaku menabung di bank Syariah menurun sebesar - 0.284 .

\section{a. Koefisien Determinasi}

Koefisien Determinasi $\left(R^{2}\right)$ pada intinya mengukur seberapa jauh kemampuan model dalam menerangkan variasi variabel dependen. Koefisien determinasi dalam penelitian ini menggunakan nilai Adjusted $R^{2}$.

Tabel 6

Koefisien Determinasi

Model Summary

\begin{tabular}{ccccc}
\hline Model & $\mathrm{R}$ & R Square & $\begin{array}{c}\text { Adjusted } \mathrm{R} \\
\text { Square }\end{array}$ & $\begin{array}{c}\text { Std. Error of } \\
\text { the Estimate }\end{array}$ \\
\hline 1 & $.810^{\mathrm{a}}$ & .656 & .627 & .66328 \\
\hline
\end{tabular}

a. Predictors: (Constant), $\mathrm{X}_{3}, \mathrm{X}_{1}, \mathrm{X}_{2}$

Berdasarkan hasil perhitungan uji determinasi didapatkan koefisien determinasi atau adjusted $\mathrm{R}^{2}$ sebesar 0.627 , hal ini menunjukkan $62 \%$ variasi perilaku menabung di bank Syariah yaitu persepsi, preferensi dan sikap. Sedangkan sisanya 100\% - 62\% = $38 \%$ dijelaskan oleh variabel lain yang tidak dimasukkan dalam model persamaan tersebut di atas.

\section{b. Uji t (Hipotesis)}

Uji t bertujuan utuk menguji pengaruh masing-masing variabel independen (pengetahuan, motivasi, persepsi risiko dan modal investasi minimal) terhadap variabel dependen (minat berinvestasi di Pasar Modal). Kriteria penarikan kesimpulan alternatif I (dengan membandingkan nilai statistik yang dihitung dengan yang ditabelnya), tolak Ho jika nilai statistik yang dihitung lebih besar dari nilai statistik tabelnya dan terima Ho jika nilai statistik yang dihitung lebih kecil dari nilai statistik tabelnya. Kriteria penarikan kesimpulan alternatif II (dengan membandingkan nilai probabilitas yang dihitung dengan nilai probabilitas yang ditetapkan), tolak Ho jika nilai probabilitas kesalahan yang dihitung lebih kecil dari probabilitas kesalahan yang ditetapkan (Sig, $a_{0.05}$ ), terima Ho jika probabilitas kesalahan yang dihitung lebih besar dari probabilitas kesalahan yang ditetapkan $\left(\mathrm{Sig}>\mathrm{a}_{0.05}\right)$ : 
Tabel 7

Hasil Uji t (Hipotesis)

\section{Coefficients $^{\mathrm{a}}$}

\begin{tabular}{|c|c|c|c|c|c|c|c|c|}
\hline & \multirow{2}{*}{ Model } & \multicolumn{2}{|c|}{$\begin{array}{c}\text { Unstandardized } \\
\text { Coefficients }\end{array}$} & \multirow{2}{*}{$\begin{array}{c}\text { Standardized } \\
\text { Coefficients } \\
\text { Beta }\end{array}$} & \multirow{2}{*}{$t$} & \multirow{2}{*}{ Sig. } & \multicolumn{2}{|c|}{ Collinearity Statistics } \\
\hline & & B & $\begin{array}{l}\text { Std. } \\
\text { Error }\end{array}$ & & & & Tolerance & VIF \\
\hline \multirow{4}{*}{1} & (Constant) & 6.370 & 1.839 & & 3.464 & .001 & & \\
\hline & $\mathrm{X}_{1}$ & .681 & .083 & .827 & 8.238 & .000 & .949 & 1.054 \\
\hline & $\mathrm{X}_{2}$ & .137 & .083 & .174 & 1.655 & .107 & .869 & 1.151 \\
\hline & $x_{3}$ & -.284 & .116 & -.258 & -2.444 & .020 & .857 & 1.167 \\
\hline
\end{tabular}

a. Dependent Variable: $\mathrm{Y}$

Pengaruh dari masing-masing variabel pengetahuan, motivasi, persepsi risiko dan modal investasi minimal secara parsial terhadap minat berinvestasi di Pasar Modal dapat dilihat dari arah tanda dan tingkat signifikansi. Tabel distribusi t dicari pada taraf signifikan (a) 5\% (0,05) dengan derajat kebebasan (df) $n-k$ atau $40-5=35$. Hasil $t_{\text {tabel }}$ diperoleh sebesar 1,689.

Variabel Persepsi (X1) berdasarkan nilai t hitung $>t$ tabel $(8.238>1.689)$, dan probabilitas kesalahan yang dihitung lebih kecil dari probabilitas kesalahan yang ditetapkan $\left(0.000<a_{0.05}\right)$ maka Ha diterima dan Ho ditolak, yang artinya secara parsial variabel independen persepsi berpengaruh positif signifikan terhadap variabel perilaku menabung di bank Syariah.

Variabel Preferensi (X2) berdasarkan nilai t hitung < t tabel $(1.655<1.689)$, dan probabilitas kesalahan yang dihitung lebih kecil dari probabilitas kesalahan yang ditetapkan ( $\left.0.107>a_{0.05}\right)$ maka Ha ditolak dan Ho diterima, yang artinya secara parsial variabel independen preferensi tidak berpengaruh terhadap variabel dependen perilaku menabung di bank Syariah.

Variabel Sikap (X3) berdasarkan nilai t hitung < t tabel $(-2,444<1.689)$, dan probabilitas kesalahan yang dihitung lebih kecil dari probabilitas kesalahan yang ditetapkan $\left(0.020<\alpha_{0.05}\right)$ maka Ha ditolak dan Ho diterima, yang artinya secara parsial variabel independen sikap tidak berpengaruh terhadap variabel dependen perilaku menabung di bank Syariah. 


\section{c. Uji F (Simultan)}

Tabel 8

Hasil Uji F

ANOVA $^{\text {a }}$

\begin{tabular}{llccccc}
\hline & Model & Sum of Squares & Df & Mean Square & F & Sig. \\
\hline \multirow{2}{*}{1} & Regression & 30.137 & 3 & 10.046 & 22.835 & $.000^{\text {b }}$ \\
& Residual & 15.838 & 36 & .440 & & \\
& Total & 45.975 & 39 & & & \\
\hline
\end{tabular}

Dependent Variable:

b. Predictors: (Constant), $\mathrm{X}_{3}, \mathrm{X}_{1}, \mathrm{X}_{2}$

Hasil pada tabel di atas telah diperoleh Fhitung sebesar 243,967 dengan taraf signifikan $(\alpha)=5 \%$ (0.05) serta diketahui $d f 1=k-1=4-1=3$ dan $d f 2$ sebesar N-k = 40-5 $=35$ adalah 2,87. Sehingga nilai Fhitung > Ftabel $(22,835>2,87)$ dan probabilitas kesalahan yang dihitung lebih kecil dari probabilitas kesalahan yang ditetapkan $(0.000<$ $a_{0.05}$ ) maka dapat disimpulkan bahwa variabel persepsi, preferensi dan sikap secara simultan berpengaruh signifikan terhadap perilaku menabung di bank Syariah.

\section{SIMPULAN}

Berdasarkan analisis data, pengujian hipotesis, dan pembahasan hasil penelitian yang telah dipaparkan sebelumnya, dapat disimpulkan bahwa:

1. Berdasarkan hasil perhitungan uji determinasi didapatkan koefisien determinasi atau adjusted R2 sebesar 0.627, hal ini menunjukkan 62\% perilaku menabung tengku dayah di bank Syariah dapat dijelaskan oleh variabel persepsi, preferensi dan sikap. Sedangkan sisanya $(100 \%-62 \%=38 \%)$ dijelaskan oleh variabel lain yang tidak dimasukkan dalam model persamaan tersebut di atas.

2. Hasil Uji t variabel persepsi (X1) menunjukan bahwa variabel persepsi berpengaruh secara signifikan terhadap perilaku menabung tengku dayah di bank Syariah, hal ini dibuktikan dengan nilai t hitung $>t$ tabel $(8.238>1.689)$, dan probabilitas kesalahan yang dihitung lebih kecil dari probabilitas kesalahan yang ditetapkan $\left(0.000<a_{0.05}\right)$ maka Ha diterima dan Ho ditolak, yang artinya secara parsial variabel independen persepsi berpengaruh signifikan terhadap variabel perilaku menabung tengku dayah di bank Syariah.

3. Hasil Uji $t$ variabel preferensi (X2) menunjukan variabel preferensi tidak berpengaruh terhadap perilaku menabung tengku dayah di bank Syariah, hal ini dibuktukan dengan nilait hitung < ttabel(1.655<1.689), dan probabilitaskesalahan yang dihitung lebih kecil dari probabilitas kesalahan yang ditetapkan $\left(0.107>a_{0.05}\right)$ maka Ha ditolak dan Ho diterima, yang artinya secara parsial preferensi tengku dayah tidak berpengaruh terhadap perilaku menabung di bank Syariah. Hal ini 
disebabkan karena sebagian tengku dayah bukan hanya memiliki tabungan pada bank Syariah saja tapi juga memiliki tabungan di bank konvensional, dan sesuai dengan pendapat yang dikemukakan oleh Kotler bahwa preferensi digambarkan sebagai sikap konsumen terhadap produk dan jasa sebagai evaluasi dari sifat koqnitif seseorang, perasaan emosional, dan kecendrungan bertindak melalui objek/ide, sehingga menabung dibank Syariah bukanlah pilihan utama tengku dayah untuk menabung.

4. Hasil Uji t variabel sikap (X3) menunjukan bahwa variabel sikap tengku dayah tidak berpengaruh terhadap perilaku menabung di bank Syariah, hal ini dibuktikan dengan nilai $t$ hitung $<\mathrm{t}$ tabel $(-2,444<1.689)$, dan probabilitas kesalahan yang dihitung lebih kecil dari probabilitas kesalahan yang ditetapkan $(0.020<$ $a_{0.05}$ ) maka Ha ditolak dan Ho diterima, yang artinya secara parsial sikap tidak berpengaruh terhadap perilaku menabung di bank Syariah. Hal ini sesuai dengan pendapat yang dikemukakan oleh Notoatmojo bahwa Sikap belum merupakan predisposisi (syarat awal) tindakan suatu perilaku, sehingga sikap tengku dayah belum menentukan perilaku untuk menabung di bank Syariah, disamping adanya kebutuhan gaji sebagian tengku dayah yang menggunakan jasa bank konvensional.

5. Hasil uji $\mathrm{F}$ pada perhitungan yang menggunakan SPSS telah diperoleh Fhitung sebesar 243,967 dengan taraf signifikan $(a)=5 \%$ (0.05) serta diketahui df1 = k-1 $=4-1=3$ dan $\mathrm{df}_{2}$ sebesar $\mathrm{N}-\mathrm{k}=40-5=35$ adalah 2,87. Sehingga nilai Fhitung $>$ Ftabel $(22,835>2,87)$ dan probabilitas kesalahan yang dihitung lebih kecil dari probabilitas kesalahan yang ditetapkan $\left(0.000<\alpha_{0.05}\right)$ maka dapat disimpulkan bahwa variabel persepsi, preferensi dan sikap tengku dayah secara simultan berpengaruh signifikan terhadap perilaku menabung di bank Syariah.

\section{PUSTAKA ACUAN}

Antonio, M. Syafi'i. 2006. Dasar-Dasar Manajemen Bank Syariah. Jakarta: Pustaka Alfabeta.

Armia, Nirzalin (2014) Teungku Dayah Dan Kekuasaan Panoptik. Jurnal Penelitian Prodi Sosiologi FISIP Universitas Malikussaleh Lhokseumawe.

Simamora, Bilson. 2000. Panduan Perilaku Konsumen. Jakarta: Gramedia.

Departemen Pendidikan Nasional. 2005. Kamus Besar Bahasa Indonesia. Jakarta: Balai Pustaka.

Djazuli, A. dan Yadi Yanuari. 2001. Lembaga-lembaga Perekonomian Umat (Sebuah Pengenalan. Jakarta: Rajawali Press.

Hafidz, AM. M. MS dkk (2014) Peran dan Potensi Kyai Pesantren dalam Pengembangan 
Lembaga Keuangan Syariah di Pekalongan Tinjauan Wom Marketing dan Buzz Marketing. Jurnal Penelitian Stain Pekalongan.

Hamidansyah, H. 2011. Kebijakan-Kebijakan Pemerintah Kabupaten Aceh Utara dalam pelaksanaan pendidikan Dayah dan Balai Pengajian. Skripsi Sarjana UINSU.

Hamidi, Dr. Jazim, SH., MH. 2000. Persepsi dan Sikap Santri Jawa Timur Terhadap Bank Syariah, Jawa Timur. Jurnal Penelitian Jawa Timur.

Juliandi, Azuar dan Irfan. 2013. Metodologi Penelitian Kuantitatif Untuk Ilmu-Ilmu Bisnis. Bandung: Citapustaka Media Perintis.

Kamal, Safwan. 2012. Faktor-Faktor Yang Mempengaruhi Keputusan Nasabah Menggunakan Dana Talangan Haji Dari Bank Muamalat (Studi Kasus Pada Jama'ah Haji KBIH Ar Raudhah Yogyakarta). Skripsi Sarjana Prodi Keuangan Islam Fakultas Syariah dan Hukum UIN Sunan Kalijaga Yogyakarta.

Kasmir. 2004. Bank Islam (Analisis Fiqih dan Keuangan). Jakarta: Pustaka SM.

Kotler, Philip dan Keller. 2007. Manajemen Pemasaran. Indonesia: PT Macanan Jaya Cemerlang.

Kreitner, Robert dan Angelo Kinicki. 2005. Perilaku Organisasi (Organizational Behavior). Jakarta: Salemba Empat.

Mangkunegara, A.P. 2009. "Perilaku Konsumen”. Bandung: PT Refika Aditama.

Murdianingsih, Sri. 2015. Penelitian tentang Analisa Persepsi Sikap dan Perilaku Santri Pondok Pesantren di Kota Salatiga Terhadap Perbankan Syariah. Skripsi, Kota Salatiga.

Mulazid, Ade Sofyan (2015) Pelaksanaan Sharia Compliance Pada Bank Syariah (Studi Kasus Pada Bank Syariah Mandiri) Jakarta. Fakultas Ekonomi Dan Bisnis Uin Syarif Hidayatullah, Jakarta, Indonesia.

Notoatmodjo, Soekidjo. 2007. Promosi Kesehatan dan Ilmu Perilaku. Jakarta: Rineka Cipta.

Perwataatmadja, Karnaen dan M. Syafi'i Antonio. 2002. Apa dan Bagaimana Bank Islam. Dana Bakti Wakaf: Yogyakarta.

Prasetyo, Bambang dan Lina Miftahul Jannah. 2005. Metode Penelitian Kuantitatif Teori dan Aplikasi. Jakarta: PT. Raja Grafindo Persada.

Rumapea, Tumpal dan Posmon Haloho. 1994. Kamus Lengkap Ekonomi. Jakarta: Erlangga.

Sudarsono, Heri. 2007. Konsep Ekonomi Islam Suatu Pengantar. Yogyakarta: EKONISIA. 
Suliyanto. 2011. Ekonometrika Terapan: Teori dan Aplikasi dengan SPSS. Yogyakarta: CV. ANDI.

Sutisna. 2001. Perilaku Konsumen dan Komunikasi Pemasaran. Bandung: PT Remaja Rosdakarya. 